\title{
DETEKSI ANALISIS EFISIENSI MODAL KERJA DENGAN PENDEKATAN TEORI SINYAL
}

\author{
Stefan Joy Karewur \\ PT. Sritex Tbk. Solo \\ Email: Stefan joy@gmail.com
}

\begin{abstract}
Abstrak
Penelitian ini bertujuan untuk menganalisis efektif penggunaan modal kerja dan efisiensi perusahaan. Penulis menggunakan metode deskriptif verifikatif dengan penelitian kuantitatif. Tujuan dari penelitian deskriptif ini adalah untuk membantu deskripsi, gambaran secara sistematis, faktual dan akurat mengenai fakta-fakta, sifat-sifat serta hubungan antar fenomena yang diselidiki kemudian di analisis untuk diambil kesimpulannya dan menguji kebenaran teori yang ada tetapi bukan untuk menciptakan teori baru. Hasil penelitian ini yaitu Rasio likuiditas yang dimiliki PT.Sritex Tbk. yang meliputi current ratio dan quick ratio dari tahun ke tahunmengalami kenaikan, Rasio aktivitas yaitu working capital turnover, receivable turnover dan inventory turnover dari tahun ke tahun mengalami peningkatan.
\end{abstract}

Kata kunci: Rasio likuiditas, Rasio aktivitas, current ratio, quick ratio.

\section{PENDAHULUAN}

Ekonomi negara kita sedang mengalami keterpurukan, diperparah lagi dengan terjadinya krisis yang melanda perekonomian diseluruh dunia. Berbagai cara dilakukan untuk membangun kembali ekonomi agar masyarakat Indonesia bisa menjadi masyarakat yang adil dan sejahtera. Semakin berkembangnya dunia usaha menuntut adanya manajemen yang baik, terutama bagi perusahaan diharapkan agar dapat bekerja secara efektif. Didirikannya sebuah perusahaan memiliki tujuan yang jelas. Adanya pendapat menyatakan tujuan perusahaan adalah mencapai keuntungan dan laba sebesar-besarnya. Perusahan adalah badan usaha yang menjalankan kegiatan di dalam bidang keuangan, industry dan perdagangan yang dilakukan secara terus menerus atau teratur, dengan terang-terangan dan dengan tujuan memperoleh keuntungan atau laba (rachmadi usaman,2000).

Menurut Molengraff, perusahaan adalah keseluruhan perbuatan yang dilakukan terus menerus, bertindak keluar untuk memperoleh penghasilan dengan cara memperdagangkan atau menyerahkan barang atau mengadakan perjanjian perdagangan. Menurut Murni Sumarni, perusahaan adalah sebuah unit

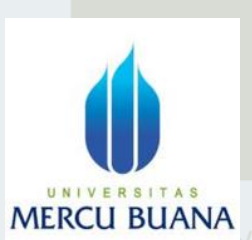

Jurnal Perilaku Dan Strategi bisnis

Vol.4 No.1, 2016

Hal. $37-43$ kegiataan produksi yang mengolah sumber daya ekonomi untuk menyediakan barang dan jasa bagi masyarakat dengan tujuan memperoleh keuntungan atau laba dan memuaskan kebutuhan masyarakat. Menurut Mucg Nurachmad, perusahan adalah bentuk usaha yang berbadan hukum atau tidak, milik perseorangan, persekutuan, atau badan hukum yang memperkerjakan pekerja dengan membayar upah atau imbalan. Tujuan dari perusahan adalah mendapatkan laba atau keuntungan. Laba adalah selisih antara jumlah 
yang di terima dari pelangan atas barang atau jasa yang dihasilkan dengan jumlah yang dikeluarkan untuk membeli sumber daya alam dalam menghasilkan barang atau jasa tersebut.

Guna mencapai tujuan perusahaan yang dikehendaki, perusahaan harus menjalankan fungsi-fungsinya dengan baik. Fungsi-fungsi perusahaan tersebut meliputi fungsi keuangan, fungsi pemasaran, fungsi sumber daya manusia dan fungsi operasional. Pengertian manajemen keuangan adalah segala aktivitas perusahaan yang berhubungan dengan bagaimana memperoleh dana, menggunakan dana, dan mengelola aset sesuai tujuan perusahaan secara menyeluruh. Untuk mencapai tujuan perusahaan yang dikehendaki,perusahaan harus menjalankan fungsi-fungsi manajemen keuangan dengan baik. Pada hakekatnya masalah manajemen keuangan adalah menyangkut keseimbangan finansial di dalam perusahaan. Dengan demikian berarti manajemen keuangan akan selalu memelihara keseimbangan antara posisi pasiva sebagai sumber dana seperti : hutang,modal, laba ditahan dengan posisi aktiva.

Modal sangat berperan dalam suatu perusahaan dan modal perusahaan digunakan untuk membelanjai aktivitas perusahaan tersebut.utnuk mengetahui tentang modal tersebut, Modal adalah hak atau bagian yang dimiliki oleh pemilik perusahaan dalam pos modal(modal saham), keuntungan atau laba yang di tahan atau kelebihan aktiva yang dimiliki perusahaan terhadap seluruh utangnya (Munawir,2001). Menurut prof. Baker, modal adalah baik yang berupa barang-barang kongkrit yang masih ada dalam rumah tangga perusahaan yang terdapat di neraca sebelah debit, maupun daya beli atau nilai tukar dari barang-barang itu yang tercatat disebelah kredit. Penggunaan modal kerja harus seefisien mungkin dalam arti modal kerja yang tersedia tidak perlu berlebihan dan tidak kekurangan. Modal kerja yang terlalu besar memungkinkan terjadinya Idle fund (dana yang menganggur). Hal ini akan mengakibatkan terjadinya inefisiensi, demikian sebaliknya modal kerja terlalu kecil akan mengakibatkan terganggunya operasi perusahaan. Berdasarkan latar belakang diatas, maka penulis ingi meneliti analisis efesiensi modal kerja.

\section{RUMUSAN MASALAH}

Berdasarkan latar belakang di atas peneliti ingin menganalisis, "Bagaimana tingkat efisiensi modal kerja perusahan PT. Sri rejeki isman, Tbk ?

\section{TEORI DAN PENGEMBANGAN HIPOTESIS}

Setiap perusahaan selalu membutuhkan modal kerja untuk membelanjai operasinya seharihari, misalkan untuk memberi uang muka pembelian bahan mentah, membayar upah karyawan, gaji pegawai, dan lain sebagainya, dimana uang atau dana yang telah dikeluarkan itu diharapkan akan dapat kembali lagi masuk perusahaan melalui hasil penjualan produksinya. Uang yang masuk berasal dari penjualan produk tersebut akan segera dikeluarkan lagi untuk membiayai operasi selanjutnya. Dengan demikian maka dana tersebut akan terus menerus berputar setiap periodenya selama hidupnya perusahaan. Mengenai pengertian modal kerja ini dapatlah dikemukakan adanya beberapa konsep, yaitu: konsep kuantitatif, kualitiatif dan fungsional, ksrena itu penelitian ini menggunakan pendekatan teori signal.

Teori signal adalah teori yang menitikberatkan pada rujukan atau sinyal atau pun tandatanda dari adanya laporan keuangan. Keadaan finansial suatu perusahaan dapat diperoleh 
dengan mengadakan interprestasi atau analisis terhadap data finansial yang ada. Data finansial tersebut tercermin dalam laporan finansialnya.Laporan finansial memberikan ikhtisar mengenai keadaan finansial perusahaan, dimana neraca mencerminkan nilai aktiva, hutang, modal sendiri dan modal asing pada saat tertentu.Sedangkan laporan laba rugi mencerminkan hasil-hasil yang dicapai selama periode tertentu yang biasanya dalam waktu satu tahun. Rasio menggambarkan suatu hubungan antara suatu jumlah tertentu dengan jumlah yang lain. Dengan rasio ini dapat menjelaskan atau memberi gambaran tentang baik buruknya keadaan atau posisi keuangan suatu perusahaan (S.Munawir, 1995 :64).

H1 : efisiensi modal kerja perusahaan PT Sritex Tbk solo

\section{METODE PENELITIAN}

Penelitian ini merupakan penelitian yang mempunyai tujuan untuk mempelajari tentang situasi modal kerja perusahaan. Penelitian ini dilakukan di PT. SRITEX Tbk yang beralamat jl. KH. Samanhudin 88 Jetis, Sukoharjo, Solo, Jawa tengah. ". Dalam penelitian yang dilakukan penulis yang menjadi sampel adalah laporan laba rugi periode 2009 - 2013 dan laporan neraca periode 2009 - 2013 PT. SRITEX Solo.

Dalam penelitian ini penulis menggunakan metode sampling non probability sampling yaitu teknik pengambilan sanpel yang tidak memberikan peluang atau kesempatan yang sama bagi setiap unsur atau anggota populasi untuk dipili menjadi sampel. Salah satu cara yang diambil oleh peneliti dalam menggunakan non probability sampling adalah purposive sampling yaitu teknik penentuan sampel dengan pertimbangan tertentu. Pertimbangan penulis dalam menentukan sampel adalah ketersediannya data dan kemudahaan memperoleh data. Adapun yang menjadi sampel penelitian ini adalah laporan neraca dan aporan keuangan laba rugi PT. Sritex Solo 2009-2013. Analisis data menggunakan regresi linear berganda.

\section{HASIL PENELITIAN}

Berawal pada tahun 1966 sebagai sebuah Perusahaan Dagang kecil di Pasar Klewer Solo dengan nama Usaha Dagang (UD). Sri Rejeki dan dipimpin oleh pendirinya yaitu H.M. Lukminto, kiprah dari perusahaan ini dimulai. Dan perusahaan ini terdaftar pada tanggal 30 Agustus 1975 di Departemen Perindustrian Jawa Tengah dan diubah dari sebuah Perusahaan Dagang menjadi sebuah Perseroan Terbatas dengan nama Sri Rejeki berdasarkan Notaris Publik nomor 48 tanggal 22 Mei 1978 serta secara resmi berubah nama menjadi PT. Sri Rejeki Isman (Sritex) pada tanggal 16 Oktober 1978. Pabrik pertamanya didirikan pada tahun 1968 di jalan Baturono nomor 81A Solo, yang memproduksi produk bleach dan dyed (pencelupan), yang kemudian perusahaan mengembangkan bisnisnya di tahun 1982 dengan mendirikan pabrik weaving (penenunan).

Dan seiring dengan perkembangan industri tekstil, Sritex melanjutkan perkembangannya, dan hingga saat ini PT. Sri Rejeki Isman telah menjadi Pabrik Garment dan Tekstil Vertikal yang Terintegrasi (an Integrated Vertical Textiles-Garments Plant), yang menempati kawasan seluas lebih dari 50 hektar di Sukoharjo, Solo, Jawa Tengah. Dan juga memiliki karyawan atau pegawai sekitar 13.500 orang. Dan untuk memenuhi permintaan atau kebutuhan pasar PT. Sri Rejeki Isman telah memiliki 3 Unit Spinning, 5 Unit Weaving, 3 Unit Dyeing Printing dan 5 Unit Garment. Menyadari kemampuan kapasitas produksinya di saatsaat permintaan pasar di titik tertinggi maka PT. Sri Rejeki Isman ikut mendirikan anak 
perusahaan yaitu Johartex di Magelang berupa Pabrik Weaving(Tenun) dan juga Jogyatex berupa Pabrik Knitting(Rajut).PT. Sri Rejeki Isman tetap mempertahankan kantor pusatnya yaitu di Jalan KH. Samanhudi 88, Jetis, Sukoharjo, Solo Jawa Tengah serta menfokuskan urusan pemasaran dengan membuka Marketing Officesdi jalan $\mathrm{KH}$. Wahid Hasyim nomor 147 Jakarta dan di jalan Slompretan nomor 117, Surabaya, Jawa Timur.

Sejalan dengan usaha utamanya di bidang Textile dan Garment, PT.Sritex sangat fleksibel dalam menerima pesanan dari konsumennya dengan jenis bahan dasar yang sangat bervariasi, seperti Rayon, Polyester, Cotton, T/C, Georgette, Dobby, Jacquard serta perpaduan komposisi dari jenis yang telah disebutkan di depan. Dalam menjalankan kegiatan usahanya, PT.Sritex didukung sepenuhnya oleh manajemen yang terdiri dari para Direktur yang memimpin Direktorat dan SBU, diawasi oleh jajaran Komisaris dan Presiden Direktur yang memiliki pengalaman di bidang industri Textile dan Garment. Didukung pula oleh karyawan-karyawan yang memiliki kapabilitas dan pengalaman yang luas baik dalam industri serta pemasaran textile dan garment. Sebagian dari produksi PT.Sritex yang cukup memberikan hasil signifikan adalah untuk produksi bahan kain dan pembuatan uniform angkatan bersenjata dari berbagai negara termasuk di dalamnya untuk Tentara Nasional Indonesia.

\section{Analisis perkembangan working capital}

Hasil penelitian menunjukkan bahwa tingkat working capital to tota assets ratio PT.Sritex Tbk. selama periode penelitian tahun 2009 sampai dengan tahun 2013 mengalami fluktuasi, yang berarti pula bahwa likuiditas perusahaan naik turun. Rata-rata working capital to total assets ratio yang diperoleh sebesar 22,06\%. Kenaikan tingakt working capital to total assets ratio terbesar dicapai pada tahun 2009 sampai dengan tahun 2010 sebesar 23,21\% yang disebabkan adanya kenaikan aktiva lancar sebesar Rp81.375.701.327, dimana kenaikan aktiva lancar tersebut diperoleh dari kenaikan kas sebesar Rp 39.128.740.736, kenaikan piutang usaha sebesar Rp 37.773.352.370, kenaikan persediaan sebesar Rp 2.302.733.448, kenaikan pajak dan beban dibayar dimuka sebesar Rp 2.022.072.033, uang muka pembelian sebesar Rp 162.680.076. selain hal tersebut di atas kenaikan working capital to total assets ratio juga dikarenakan adanya penurunan hutang lancar sebesar Rp 88.227.444.965. penururan tingkat working capital to total assets ratio terbesar terjadi pada tahun 2012 sampai pada tahun 2013 yaitu sebesar $14,12 \%$. Hal ini disebabkan adanya kenaikan hutang lancar sebesar Rp 83.621.872.632 dan adanya penurunan jumlah total aktiva sebesar Rp 76.223.626.723 yang di sebabkan berkurangnnya aktiva tetap sebesar Rp 43.398.536.330 dan aktiva lancar sebesar Rp 32.825.090.393.

Working capital to total assets ratio sebesar $22.06 \%$ mempunyai arti setiap Rp 1,00 aktiva yang dimiliki perusahaan rata-rata 0,2206 rupiah merupakan modal kerja bersih. Semakin besar rasio ini berarti semakin besar modal kerja yang dimiliki perusahaan guna melaksanakan operasinya. Hal ini menunjukan bahwa perusahaan mampu menunaikan kewajiban jangka pendek yang dibiayai dengan aktiva lancar dengan lebih cepat. Dengan kata lain tingakt likuiditasi perusahaan lebih terjamin tingkat perputaran modal kerja PT.Sritex Tbk. selama periode penelitian mengalami fluktuasi penurunan tingkat perputaran modal kerja terbesar terjadi pada tahun 2009 sampai pada tahun 2010. Hal ini disebabkan oleh adanya kenaikan tingakt penjualan yang lebih kecil dari kenaikan 
tingkat modal kerjanya. Kenaikan working capital turn over tertinggi terjadi pada tahun 2012 ke tahun 2013. Walaupun jumlah penjualan menurun sebesar Rp 111.882.929.439 tetapi penurunan tersebut lebih kecil dibandingkan dengan penurunan modal kerja sebesar Rp 116.428.963.025 sehinga menyebabkan tingakt perputaran modal kerja naik .

Rentabilitas ekonomis yang diperoleh PT.Sritex Tbk. selama periode penelitian tahun 2009 sampai pada tahun 2013 mengalami fluktuasi dengan rata-rata rentabilitas ekonomis sebesar $37,22 \%$. Nilai rentabilitas ekonomis tersebut menjelaskan adanya perolehan laba rata-rata sebesar $37,22 \%$ setiap dilakukan penambahan satuan modal. Dengan kata lain setiap dilakukan investasi yang diukur dengan adanya penambahan modal sebesar Rp 1,00 akan mendatangkan laba atau keuntungan sebesar Rp 0,3722. Kenaikan rentabilitas ekonomis terbesar yang diperoleh perusahaan dicapai pada tahun 2011 - tahun 2012 sebesar 29,98\%. Hal ini disebabkan oleh adanya peningkatan pendapatan atau laba sebesar Rp 125.966.036.574. Dimana peningkatan laba tersebut terjadi karena adanya penurunan harga pokok penjualan sebesar Rp 69.429.112.485 dan penurunan beban lain-lain sebesar Rp 77.689.557.673. Penurunan tingkat rentabilitas ekonomis yang paling besar terjadi pada tahun 2009- tahun 2011 sebesar 7,95\% yang disebabkan oleh adanya kenaikan modal tetapi penggunaannya tidak maksimal sehingga banyak modal yang digunakan dengan tidak maksimal sehingga banyak modal yang digunakan dengan tidak produktif akibatnya laba yang dihasilkan tidak sebesar tahun sebelumnya.

Operating ratio yang diperoleh PT.Sritex Tbk. selama periode penelitian mengalami fluktuasi yang berarti pula bahwa efisiensi perusahaan naik turun. Rata-rata operating ratio yang diperoleh sebesar $60,70 \%$. Kenaikan tingkat operating ratio terbesar yang diperoleh perusahaan pada tahun 2012 ke tahun 2013 yaitu sebesar 5,72\% yang disebabkan adanya kenaikan harga pokok penjualan dan juga penurunan jumlah penjualan, walaupun terjadi penurunan biaya operasi. Penurunan operating ratio terbesar dicapai pada tahun 2010-tahun2011 yaitu sebesar 13,25\% hal ini disebabkan adanya kenaikan jumlah penjualan bersih sementara itu harga pokok penjualan mengalami penurunan, walaupun biaya operasi mengalami kenaikan tetapi tidak terlalu mempengaruhi penurunan tingkat operating ratio. Operating ratio sebesar $60,70 \%$ mempunyai arti bahwa setiap Rp 1,00 hasil penjualan, rata-rata 0,6070 rupiah terserap dalam biaya. Semakin kecil operating ratio ini, berarti besarnya rupiah untuk memperoleh laba.

Dari analisis data dengan time series metode least square yang ada di lampiran 19 diperoleh persamaan trend linier untuk working capital to total assets sebagai berikut : $\mathrm{Y}=2206+1,88 \mathrm{X}$

Dari persamaan tersebut diketahui besarnya nilai (a) yaitu 22,06 yang berarti bahwa apabila nilai X berada pada titik nol (tahun dasar yaitu tahun 2011), maka working capital to total assets adalah sebesar 22,06\%. Sedangkan nilai koefisiensi trend (b) yaitu 1,88 (positif), mengandung arti bahwa tingkat working capital to total assets selama periode penelitian tahun 2009 sampai dengan 2013 mengalami peningkatan.Sebuah perusahaan dikatakan likuid apabila perkembangan working capital to total assets positif. Oleh karena 
nilai koefisien trend linier untuk working capital to total assets yang diperoleh perusahaan adalah positif $(1,88)$ dengan demikian perusahaan dapat dikatan likuid.

\section{Analisis perkembangan rentabilitas ekonomis}

Dari analisis data dengan time series metode least square yang ada di lampiran 20 diperoleh persamaan trend linier untuk rentabilitas ekonomis sebagai berikut :

$Y=37,22+10,56 X$

Dari persamaan tersebut diketahui besarnya nilai (a) yaitu 37,22\% yang berarti bahwawa apabila nilai $X$ berada pada titik nol (tahun dasar yaitu 2011), maka rentabilitas ekonomis yang diperkirakan adalah sebesar 37,22\% sedangkan nilai koefisien trend (b) yaitu 10,56 mengandung arti bahwa efisieni rentabilitas ekonomis selama periode peneltian tahun 2009 sampai dengan tahun 2013 mengalami peningkatan. Sebuah perusahaan dikatakan mempunyai tingkat efisiensi yang baik apabila perkembangan rentabilitas ekonomis positif. Oleh karena nilai koefisien trend linier untuk rentabilitas ekonomis positif. Oelh karena nilai koefisien trend linier untuk rentabilitas ekonomis yang diperoleh perusahaan adalah positif $(10,56)$, maka efisiensi penggunaan modal dilihat dari tingakat rentabilitas ekonomis dari tahun ke tahun mengalami peningkatan diterima.

\section{Analisis perkembangan operating ratio}

Dari analisis data dengan metode time series least square yang ada di lampiran 21 diperoleh persamaan trend linier untuk operating ratio sebagai berikut :

$Y=60,71-5,52 X$

Dari persamaan tersebut diketahui bahwa besarnya nilai (a) yaitu sebesar 60,71 yang berarti apabila nilai $X$ berada pada titik nol (tahun dasar yaitu tahun 2011), maka operating ratio yang diperkirakan adalah sebesar $60,70 \%$. Sedangkan nilai koefisien trend (b) sebesar $-5,52$ (negatif) yang berarti bahwa operating ratio selama periode penelitian tahun 2009 sampai dengan tahun 2013 mengalami penurunan. Sebuah perusahan dikatakan mempunyai efisiensi usaha yang baik apabila perkembangan operating rationya negatif atau menurun. Operating ratio yang semakin menurun ini mencerminkan kemampuan perusahaan dalam menjalankan usahannya semakin efisien, khusunya dalam pengendalian biaya-biaya usaha. Oleh karena itu nilai koefisien trend untuk operating ratio negatif $(-5,52)$ sehingga dengan demikian hipotesis yang menyatakan efisiensi usaha ditinjau dari analisis ratio khususnya operating ratio dari tahun ke tahun mengalami peningkatan atau usaha yang dijalankan perusahaan semakin efisien diterima.

\section{KESIMPULAN}

1. Rasio likuiditas yang dimiliki PT.Sritex Tbk yang meliputi current ratio dan quick ratio dari tahun ke tahunmengalami kenaikan. Hal ini dibuktikan dengan adanya efisiensi modal kerja setelah diuji dengan menggunakan metode least square menunjukan perkembangan working capital to total assets ratio yang diperoleh dari persamaan trend linier yaitu $Y=2206+1,88 X$ yang berarti rata-rata peningkatan efisiensi penggunaan modal kerjanya adalah positif $(1,88)$.

2. Rasio aktivitas yaitu working capital turnover, receivable turnover dan inventory turnover dari tahun ke tahun mengalami peningkatan.

3. Rasio profitabilitas yang meliputi rentabilitas ekonomis dan operating ratio diperoleh kesimpulan bahwa efisiensi usaha PT.Sritex Tbk berdasarkan 
4. rentabilitas ekonomis setelah diuji menggunakan pengujian statistik time series metode least square menunjukan perkembangan rentabilitas ekonomis yang diperoleh dari persamaan trend $\mathrm{Y}=37,22+10,56 \mathrm{X}$ yang berarti rata-rata peningkatan efisiensi pengunaan modalnya adalah positif $(10,56)$ sedangkan untuk operating ratio diperoleh persamaan trend linier yaitu $Y=60,71-5,52 X$, yang berarti bahwa operating ratio selama periode penelitian negatif $(-5,52 X)$, sehingga efisiensi usaha cenderung meningkat diterima. Sehingga hipotesis yang menyatakan efisiensi penggunaan modal kerja dan efisiensi usaha dilihat dari analisis rasionya sudah efisiensi dapat diterima.

\section{SARAN}

PT.Sritex Tbk sebaiknya tetap mempertahankan atau meningkatkan efisiensi penggunaan modal kerja karena menunjukan penignkatan yang cukup berarti. Agar efisiensi usaha yang dilakukan perusahaan semakin meningkat, kiranya perlu ditinjau kembali perputaran modal kerja dan perputaran persediaannya.

\section{DAFTAR PUSTAKA}

Amudi pasaribu, pengantar statistik. Jakarta, Ghalia, 1983.

Bambang Riyanto, Dasar-dasar pembelanjaan perusahaan. Yogyakarta, BPFE, 1995.

Munawir S,. Analisis Laporan Keuangan. Yogyakarta, Liberty, 1995 Rollin Niswonger C., Prinsip-prinsip Akuntansi. Jakarta, Erlangga, 1995. Samsubar Saleh, Statistik Deskriptif. Yogyakarta, UPP AMP YKPN, 1990. Syafaruddin Alwi DRS., MS., Alat-alat Analisis Dalam Pembelanjaan. Yogyakarta, Andi Offset, 1993 